\title{
NEGARA HUKUM DAN PEMBANGUNAN NASIONAL BERWAWASAN HUKUM
}

\author{
Jumadi \\ Universitas Islam Negeri (UIN) Alauddin Makassar \\ Email: Jumadirahman263@yahoo.com
}

\begin{abstract}
The national development of legal insight is based on the principles of state law and legal insight that includes the development of the legal systen, the general draft of law policy, the implementation of law enforceable state, and the orientation of legal norms. The enforcement orientation must meet the requirements of legal material and law enforcement officers. Efforts to reform the material of national law must be in accordance with the needs of the times and in line with the development of the velues of community justice by socializing the material of national law through a real program and widely disseminated and suistainable so taht applicable legal norms are known, understood, recognized and accepted with awareness by every citizen.
\end{abstract}

Keywords: State of Law, National Development, Legal Insight

\begin{abstract}
Abstrak
pembangunan nasional berwawasan hukum didasari oleh prinsip negara hukum dan wawasan hukum yang mencakup pembangunan sistem hukum, rancangan umum kebijakan hukum, penyelenggaran negara berwawasan hukum, dan orientasi norma hukum. Adapun orientasi penegakannya harus memenuhi syarat materi hukumnya dan aparat penegak hukum. Upaya pembaruan materi hukum nasional harus sesuai kebutuhan zaman dan sejalan dengan perkembangan nilai-nilai keadilan masyarakat dengan cara mensosialisasikan materi hukum nasional melalui suatu program nyata dan dimasyarakatkan secara luas dan berkesinambungan sehingga norma hukum yang berlaku diketahui, dimengerti, diakui, dan diterima dengan kesadaran oleh setiap warga negara.
\end{abstract}

Kata Kunci: Negara Hukum, Pembangunan Nasional, Wawasan Hukum 


\section{PENDAHULUAN}

$\mathrm{P}$ erbedaan yang cukup sigifikan UUD Negara RI Tahun1945 sebelum dan sesudah perubahan terdapat pada wawasan negara hukum. Hukum adalah panglima dan solusi dari semua masalah kenegaraan dan pembangunan nasional. Hukum sebagai orientasi penyelengaraan pemerintahan dan kehidupan msyarakat bangsa. Hal itulah sehingga tegas dan jelas tertuang dalam Pasal 1 ayat (3) UUD NRI Tahun 1945.

Dari ketegasan negara berdasar atas hukum di atas, dapat dikatakan bahwa permasalahan yang hadapi sebagai bangsa, khususnya, dalam konteks negara hukum sangatlah kompeks. Begitu banyak dan bervariasi persoalan yang perlu diselesaikan oleh bangsa negara, agar cita-cita negara hukum yang diimpikan oleh 'the founding fathers' dapat diwujudkan. Pada masa transisi ini konstitusi hasil perubahan dimanfaatkan dengan sebaik-baiknya untuk menata lebih maju (sesuai kebutuhan modern) sistem hukum nasional Indonesia yang bersifat menyeluruh (comprehensive) dan mencakupi (comprehensible). Karena itu, diperlukan adanya desain kebijakan hukum yang dapat dijadikan dasar berpijak, sehingga dalam jangka panjang, cita-cita negara hukum dapat benar-benar diwujudkan dalam kenyataan.

Pembangunan hukum nasional itu sendiri masih perlu dikemnbangkan dengan baik dan serius. Bertitik tolak pada cita-cta pemangunan hukum, apakah mendesak perlu menggiatkan upaya pembaruan materi hukum nasional sesuai dengan kebutuhan zaman dan sejalan dengan perkembangan nilai-nilai keadilan yang hidup dalam masyarakat. Materi hukum nasional yang ada dan yang telah diperbarui perlu disosialisasikan secara bersengaja dan dimasyarakatkan secara luas dan terus menerus, sehingga norma hukum yang berlaku menjadi diketahui, dimengerti, diakui, dan diterima dengan kesadaran oleh setiap warga negara.

Demkian pula pembangunan sistem hukum nasional yang lamban, menyendat tujuan hukum bangsa, bahkan sistem penegakan hukum yang masih dirasakan menggugah keadilan. Pelaksanaannya kurang didukung oleh sistem kelembagaan maupun kualitas aparat yang bekerja efektif, responsif, rasional dan impersonal terhadap setiap pelanggaran hukum yang terjadi.

Keseluruhan masalah dalam negara hukum tersebut di atas, baik mengenai sistemnya, lembaga dan kewenangannya termasuk para pelaksananya, ternyata menghadapi pula kendala teknologi, antara lain kurang efekifnya dukungan sistem 
informasi dan administrasi hukum yang modern, ${ }^{1}$ sehingga tujuan mempermudah bekerjanya sistem hukum secara keseluruhan, masih tersendat. Dengan demikian negara hukum modern yang sedang menganut pembangunan berwawasan hukum menjadi semakin urgen untuk diwujudkan.

\section{PEMBAHASAN}

\section{A. Makna Negara Hukum}

Para pendiri negara Indonesia modern mengimpikan tujuan negara (staats idee) Indonesia sebagai negara hukum. Penjelasan umum Undang-Undang Dasar 1945 (sebelum diubah), menyebut konsep negara hukum tersebut dengan "rechtsstaat" lawannya "machtsstaat" (negara kekuasaan). Ketika UUD 1945 diganti dengan UUD RIS pada tahun 1949, selanjutnya berlaku UUD Sementara pada tahun 1950, ide negara hukum itu jelas secara tegas disebut dalam Pasal 1 ayat (1) kedua konstitusi terakhir itu. Berarti sejak kemerdekaan Indonesia, konsep negara hukum selalu tetap ada dalam konstitutionalismenya.

Perwujudan ide negara hukum itu terbukti tidaklah gamang. Selama periode kepemimpinan Presiden Soekarno, politik dianggap paling menentukan dalam dinamika kehidupan kenegaraan Indonesia bukanlah hukum. Sementara itu, pada periode Orde Baru, yang dianggap paling menentukan adalah pembangunan ekonomi. Berdasarkan kedua hal itu muncul istilah politik atau ekonomi sebagai panglima dengan maksud membandingkan wawasan kepemimpinan negara kurun waktu dari awal kemerdekaan ke masa Orde Lama serta di masa Orde Baru. Saat ini, bangsa kita memasuki era reformasi. Wawasan kepemimpinan nasional berubah dengan menggunakan dasar konstitusi mengedepankan hukum sesuai dengan cita-cita negara hukum Indonesia modern. Dengan kata lain inilah saat yang tepat untuk mewujudkan cita-cita negara hukum yang dalam istilah Inggeris "the rule of law" atau dalam istilah Jerman disebut dengan "rechtsstaat".

Ide negara hukum juga berkaitan dengan konsep "nomocracy" yang berasal dari perkataan 'nomos' dan 'cratos' (kratein). Istilah nomos berarti norma, sedangkan 'cratos' adalah kekuasaan. Bayangan intinya adalah norma atau hukum sebagai faktor penentu dalam penyelenggaraan kekuasaan. Berarti nomokrasi itu berkaitan erat dengan ide kedaulatan hukum atau prinsip hukum sebagai kekuasaan tertinggi. Ide nomokrasi itu sesungguhnya telah lama dikembangkan

\footnotetext{
1 Yang dimaksud dengan modern disini, sesuai dengan tingkat kemampuan sistem hukum kita, adalah digunakannya jasa teknologi informasi seperti computer dan internet, sehingga sistem informasi dan administrasi hukum nasional kita bersifat 'computerized' dan 'on-line'.
} 
sejak dari zaman Yunani Kuno, kemudian ditemukan dalam buku Plato berjudul "Nomoi" (Inggeris=Laws). Dicey ${ }^{2}$ kembangkan kemudian mengaitkannya dengan prinsip “rule of law”di Inggeris. Selanjutnya berkembang di Amerika Serikat melahirkan jargon "the rule of law, and not of man" (sesungguhnya yang dianggap sebagai pemimpin adalah hukum itu sendiri, bukan orang).

Di Eropah Kontinental konsep negara hukum dikembangkan antara lain oleh Immanuel Kant, Paul Laband, Julius Stahl, Fichte, dan lain-lain dengan menggunakan istilah Jerman, yaitu 'rechtsstaat'. Sedangkan tradisi Anglo Amerika atas kepeloporan A.V. Dicey negara hukum dengan sebutan "The Rule of Law"3. Julius Stahl menyebut istilah 'rechtsstaat' mengandung empat elemen penting, yaitu: (1) perlindungan hak asasi manusia; (2) pembagian kekuasaan; (3) pemerintahan berdasarkan undang-undang; dan (4) peradilan tata usaha Negara. Sedangkan menurut A.V. Dicey terdapat tiga ciri penting dalam "The Rule of Law" yang dikembangkan di Negara hukum, yaitu: (1) supremacy of law; (2) equality before the law; dan (3) due process of law.

Prinsip "rechtsstaat”dari Julius Stahl apabila digabungkan dengan prinsip 'Rule of Law' A.V. Dicey tersebut di atas, makam akan kelihatan ciri-ciri negara hukum modern saat ini. Demikian pula "The International Commission of Jurist" menambahkan prinsip peradilan bebas dan tidak memihak (independence and impartiality of judiciary) yang di zaman sekarang makin dirasakan mutlak diperlukan dalam setiap negara demokrasi. Menurut "The International Commission of Jurists" Prinsip yang dianggap sebagai ciri penting negara hukum itu adalah: (1) negara harus tunduk pada hukum; (2) pemerintah menghormati hak-hak individu; dan (3) peradilan yang bebas dan tidak memihak.

Utrecht menyebut Negara hukum modern ${ }^{4}$, berupaya mencapai keadilan di dalamnya. Karena itu, Wolfgang Friedman menegaskan bahwa dalam konsepsi negara hukum itu, keadilan tidak serta-merta akan terwujud secara substantif, terutama karena pengertian orang mengenai hukum itu sendiri dapat dipengaruhi oleh aliran pengertian hukum formil dan dapat pula dipengaruhi oleh aliran pikiran hukum materiel. Jika hukum dipahami secara kaku dan sempit dalam arti

2 A.V. Dicey, An Introduction to the Study of the Law of the Constitution, Macmillan, edisi tahun 1971.

${ }^{3}$ Untuk diskusi yang mendalam mengenai konsep 'rule of law' ini dapat dibaca karya Franz Neumann, The Rule of Law: Political Theory and the Legal System of Modern Society, Leamington Spa and Heidelberg, 1986.

${ }^{4}$ Utrecht, Pengantar Hukum Administrasi Negara Indonesi (Ichtiar : Jakarta, 1962), h. 9. 
peraturan perundang-undangan semata, niscaya pengertian negara hukum yang dikembangkan juga bersifat sempit dan terbatas serta belum tentu menjamin keadilan substantive. Dengan demikian berkebanglah istilah "the rule of just law" untuk memastikan bahwa dalam pengertian "the rule of law" tercakup pengertian keadilan yang lebih esensiel.

Dari uraian-uraian di atas, Jimy Ashshiddiqi merumuskan sepuluh prinsip pokok negara hukum yang berlaku di zaman sekarang ini. Kesepuluh prinsip pokok tersebut merupakan pilar utama yang menyangga berdiri tegaknya suatu Negara Hukum modern ${ }^{5}$, yakni: (1) supremasi hukum (supremacy of law); (2) persamaan dalam hukum (Equality before the Law); (2) asas legalitas (due process of law);(3) pembatasan kekuasaan (checks and balances); (3) organ-organ eksekutif yang bersifat independen (independent body); (4) peradilan bebas dan tidak memihak (independent and impartial judiciary); (5) Peradilan Tata Usaha Negara (administrative court); (6) Peradilan Tata Negara (Constitutional Court); (7) perlindungan hak asasi manusia (human rights protection);(8) bersifat demokratis (democratische rechtsstaat); (9) berfungsi sebagai sarana mewujudkan tujuan kesejahteraan (welfare rechtsstaat); (10) transparansi dan kontrol social; dan ditambah lagi satu oleh Muhammad Tahir Azhary ${ }^{6}$ menjadi (11) berkeTuhanan Yang Maha Esa.

\section{B. Pembangunan Nasional Berwawasan Hukum}

\section{Wawasan hukum}

Dari uraian di atas, dapat dikemukakan bahwa dalam negara berdasarkan hokum. Pada hakikatnya, terhadap semua kegiatan penyelenggaraan pembangunan senantiasa berwawasan hukum. Segala dinamika kehidupan kenegaraan haruslah didasarkan atas hukum sebagai pegangan utama, bukan politik atau ekonomi semata. Memang harus diakui, bahwa cita-cita ideal negara hukum (rechtsstaat) itu tidak mudah diterapkan. Ketika UUD 1945 dirancang oleh BPUKI, wawasan negara hukum itu telah mewarnai corak pemikiran

\footnotetext{
${ }^{5}$ Bandingkan dengan Muhammad Tahir Azhary, Negara Hukum: Suatu Studi tentang PrinsipPrinsipnya Dilihat dari Segi Hukum Islam, Implementasinya pada Periode Negara Madinah dan Masa Kini, Bulan Bintang, Jakarta, 1992.

${ }^{6}$ Bandingkan dengan Muhammad Tahir Azhary, Negara Hukum: Suatu Studi tentang PrinsipPrinsipnya Dilihat dari Segi Hukum Islam, Implementasinya pada Periode Negara Madinah dan Masa Kini, Bulan Bintang, Jakarta, 1992.
} 
ketgatanegaraan yang kemudian tuangkan ke dalam rumusan UUD 1945 yang ditetapkan pada taggal 18 Agustus 1945.

Pada masa pemerintahan Presiden Soekarno, yakni sejak tahun 1945 sampai tahun 1966, yang dianggap panglima dalam penyelenggaraan negara Republik Indonesia adalah politik bukan hukum. Pada era ini inilah dikenal adanya istilah politik sebagai panglima. Sedangkan, di masa pemerintahan Presiden Soeharto, yakni sejak tahun 1967 sampai tahun 1998, yang dianggap sebagai panglima adalah ekonomi, juga bukan hukum. Semua keputusan seakanakan diabdikan untuk kepentingan pembangunan ekonomi, khususnya kepentingan untuk membangun pertumbuhan ekonomi nasional.

Ketika memasuki era reformasi (jatuhnya rezim Orde Baru) pada bulan Mei 1998, bangsa berpeluang mengubah wawasan pembangunan nasional dan wawasan penyelenggaraan negara dari berwawasan politik dan ekonomi pada era sebelumnya menjadi berwawasan hukum. Arah reformasi ke arah perwujudan cita-cita negara yang berwawasan hukum itu. Terhadap tujuan berwawasan hukum itu, hukum dan sistem hukum itu sendiri perlu terlebih dahulu direformasi.

Sebagaimana yang menjadi tuntutan gerakan reformasi pada tahun 1998 itu, ialah perlu segera dilakukan tindakan reformasi menyeluruh bidang politik, ekonomi dan reformasi hukum. Kenyataannya, kebutuhan paling mendesak adalah reformasi hukum, karena bersifat instrumental dalam rangka perwujudan gagasan reformasi politik dan ekonomi secara menyeluruh. Maknanya sebagai langkah dan upaya reformasi yang dilakukan di bidang politik dan ekonomi itu, pada pokoknya akan membentuk norma aturan hukum yang baru. Dengan demikian gagasan perbaikan yang dicita-citakan dituangkan secara resmi dalam bentuk hukum yang dapat dijadikan pegangan normatif di masa depan.

\section{Pembangunan sistem hukum}

Dengan wawasan yang demikian itu, pembangunan nasional Indonesia dalam arti pembangunan hukum nasional mencakup komponen pembangunan "structural-institutional", komponen pembangunan "cultural-behavioral", dan pembangunan hukum instrumental yang menyangkut materi hukum nasional. Ketiga komponen pembangunan hukum tersebut berlaku, baik dalam kerangka fungsi-fungsi legislasi, administrasi, maupun fungsi judicial. Dalam ketiga fungsi itu, masing-masing terkait adanya institusi-institusi hukum, adanya unsur subjek hukum pendukungnya, dan instumen normatif yang mengaturnya. Dalam arti yang lebih sempit, instrument peraturan perundang-undangan itu sendiri terkait 
pula dengan kegiatan pembuatannya (law making), kegiatan pemasyarakatannya (law promulgation and law socialisation), dan kegiatan penegakannya (law enforcement) yang di dalamnya juga terkait dengan elemen institusionalnya, elemen manusianya, dan elemen-elemen proseduralnya. Untuk menunjang keseluruhan fungsi dan aktifitas terkait dengan hukum itu diperlukan (a) desain makro kebijakan pembangunan hukum nasional yang menyeluruh, dan (b) pusat administrasi informasi hukum yang terpadu yang mencakup informasi berkenaan dengan peraturan (regelen), penetapan administrasi negara (beschikkingen), dan putusan-putusan peradilan (vonis), serta putusan-putusan penyelesaian sengketa lain, seperti arbitrase dan "despute desolution" lainnya. Sistem informasi terpadu tersebut diharapkan dapat pula mencakup kebutuhan baik untuk tingkat pusat maupun sampai ke tingkat daerah dan bahkan tingkat desa di seluruh Indonesia.

Pemahaman mengenai sistem hukum nasional juga perlu diperluas sehingga mencakup pengertian yang lebih menyeluruh. Sistem hukum dapat dikaitkan dengan pengertian atau dilihat dari cabang kekuasaan, dan dapat pula dari proses kegiatannya. Dari segi cabang kekuasaannya, sistem hukum itu mencakup:

a. Kekuasaan legislatif (legislative power), yaitu cabang kekuasaan yang menentukan arah kebijakan pemerintahan dan menetapkan peraturan perundang-undangan pada tingkatan tertentu, yaitu biasanya dalam bentuk Undang-Undang Dasar dan Undang-Undang;

b. Kekuasaan eksekutif (executive branch), yaitu cabang kekuasaan yang menjalankan fungsi pemerintahan dan melaksanakan arahan-arahan yang ditentukan oleh atau berdasarkan UUD dan UU; dan

c. Kekuasaan judikatif atau judicial (judiciary), yaitu cabang kekuasaan yang menguji materi peraturan dan menilai pelaksanaan undang-undang serta mengadili perkara-perkara pelanggaran hukum pada umumnya.

Dari segi lain (proses kegiatannya), sistem hukum nasional itu juga meliputi fungsi-fungsi atau kegiatan-kegiatan;

a. Pembuatan hukum (law making), yaitu menyangkut kegiatan-kegiatan penelitian, perencanaan, pengkajian, perancangan, pembahasan dan pengesahan rancangan peraturan menjadi peraturan resmi;

b. Pengadministrasian hukum (the administration of law), yaitu menyangkut kegiatan pengadministrasian dalam arti sempit berupa penomeran, penerbitan, pengumuman, dan pendokumentasian ataupun dalam arti luas mencakup pelaksanaan atau penerapan hukum dalam praktek 
penyelenggaraan negara. Dalam pengertiannya yang sempit, misalnya, dapat dipertanyakan sejauhmana produk-produk peraturan perundangundangan, keputusan-keputusan pejabat administrasi negara, dan vonisvonis hakim mulai dari tingkat pusat sampai ke daerah-daerah di seluruh Indonesia telah terdokumentasikan dengan baik, tentu masih menjadi tanya tanya besar;

c. Pemasyarakatan hukum (the socialization and promulgation of law), yaitu menyangkut kegiatan penyebarluasan dan pemasyarakatan infomasi peraturan perundang-undangan. Meskipun dalam ilmu hukum dikenal adanya teori fiktie yang menentukan bahwa pada saat suatu peraturan diundangkan maka pada waktu yang bersamaan semua orang sudah dianggap tahu hukum. Padahal dalam kenyataannya, apalagi di lingkungan negara sebesar dan seberagam dengan tingkat perkembangan yang tidak merata seperti Indonesia, teori fiktie itu hanyalah teori hayalan. Untuk mengatasi kelemahannya itulah diperlukan langkah-langkah bersengaja untuk memasyarakatkan segala peraturan perundang-undangan dengan sungguh-sungguh; dan

d. Penegakan hukum (the enforcement of law), yaitu menyangkut kegiatan pengawasan terhadap penyimpangan, penyelidikan, penyidikan, penuntutan, penghakiman, dan pemidanaan atau penetapan vonis oleh hakim, serta kegiatan eksekusi putusan, dan kegiatan pemasyarakatan kembali (resosialisasi).

Keempat kegiatan itu ada di tingkat pusat dan ada pula di daerah. Bahkan, dalam rangka pembudayaan hukum dan tradisi taat hukum, keseluruhan kegiatan itu juga harus dilihat dalam konteks kehidupan di lapisan pedesaan atau masyarakat desa yang berdasarkan konsepsi UU No. 23/2014 tentang Pemerintahan Daerah dan UU. No. 6 Tahun 2014 Tentang Desa disebut sebagai "self governing communities". Dengan demikian, semua kegiatan tersebut di atas dapat dilihat, baik pada tingkat pusat, daerah-daerah provinsi dan kabupaten/kota, serta tingkat desa, Dalam ketiga cabang kekuasaan dan tiga jenis kegiatan hukum tersebut serta di tiap tingkatan pusat, daerah dan desa tersebut di atas, terkait adanya tiga elemen sistem hukum sekaligus, yaitu:

a. Institusi hukum;

b. Tradisi dan kultur hukum; dan

c. Perangkat instrumental materi normatifnya berupa peraturan tertulis ataupun peraturan tidak tertulis. 


\section{Rancangan Umum Kebijakan Hukum}

Dalam rangka pembangunan nasional yang berwawasan Hukum dan negara hukum, perlu disusun suatu rancangan jangka panjang yang tidak menjadikan hukum hanya sebagai satu sektor dalam kerangka pembangunan nasional yang menyeluruh. Secara simbolik Undang-Undang Dasar adalah Kepala Negara Republik Indonesia sekaligus berfungsi menjadi semacam "kitab suci dari syar'at bernegara" (civil religion) bagi segenap warga negara. Semua warga negara mempunyai kedudukan yang sama di hadapan hukum dan pemerintahan. Bahkan semua manusia dijamin kemerdekaannya memiliki dan menggunakan hak-hak asasinya masing-masing. Semua perbuatan atau kegiatan warga negara yang berkenaan dengan negara dan masalah-masalah kenegaraan harus dilakukan atas dasar peraturan perundang-undangan yang pada pokoknya ditujukan untuk mencapai dan mewujudkan tujuan bernegara. Tidak ada institusi apapun yang memiliki kekuasaan apapun dalam negara Indonesia yang tidak terbatas dan dibatasi. Tidak ada dan tidak boleh ada peraturan perundang-undangan apapun yang ditetapkan secara sewenang-wenang tanpa prosedur demokrasi, tanpa pembatasan dan pengawasan, termasuk keterbukaannya untuk dikontrol secara demokratis oleh masyarakat luas. Dalam negara hukum Indonesia, sistem peradilan bekerja secara merdeka dan tidak memihak, dan bagi setiap warga negara yang dirugikan oleh keputusan pejabat administrasi negara terbuka peluang yang adil untuk menuntut keadilan melalui peradilan tata usaha negara yang juga merdeka dan tidak memihak, kecuali kepada kebenaran dan keadilan itu sendiri.

\section{Penyelenggara negara berwawasan hukum}

Dari norma-norma tersebut di atas yang penting disadari adalah, pertama, bahwa dalam negara hukum Republik Indonesia, yang sesungguhnya menjadi pemimpin tertinggi adalah konstitusi, yaitu UUD, sesuai prinsip "the rule of law, and not of man". Kedua, konstitusi dan norma-norma hukum yang berada di bawahnya terjalin sebagai satu kesatuan sistem aturan kenegaraan bagi setiap warga negara, yang menjadikan setiap warga negara bersamaan kedudukannya, hak dan kewajibannya di hadapan hukum dan pemerintahan. Ketiga, semua tindakan dan kebijakan pemerintahan, termasuk kebijakan pembangunan nasional haruslah didasarkan atas aturan hukum yang telah ditetapkan lebih dulu sesuai dengan asas legalitas. Hal ini tidak perlu menyebabkan proses pemerintahan 
mengabaikan pentingnya "mission driven", karena pada hakikatnya hukum itu sendiri justru dimaksudkan untuk berfungsi instrumental terhadap upaya perwujudan missi yang diemban itu.

\section{Orientasi norma hukum}

Dari uraikan di atas, dapat diketahui bahwa istilah hukum dan sistem hukum itu sendiri sebenarnya sangatlah luas cakupan pengertiannya. Jika hukum dimengerti hanya sebagai perangkat peraturan yang bersifat tertulis, maka pengertian demikian jelaslah merupakan pengertian yang paling sempit dari kata hukum itu. Dalam arti yang tidak terlalu luas, tetapi dalam bentuknya yang paling nyata apa yang dikenal dengan sebutan hukum itu sebenarnya menyangkut tiga jenis putusan hukum, yaitu:

a. Bentuk peraturan yang berisi materi aturan sebagai hasil kegiatan pengaturan terhadap kepentingan umum (regels). Biasanya bentuk seperti inilah yang tepat disebut sebagai peraturan perundangundangan;

b. Bentuk keputusan-keputusan pejabat-pejabat administrasi negara berupa keputusan (beschikkingen) yang tidak bersifat mengatur, tetapi mengandung konsekwensi hak dan kewajiban dalam lalu lintas hukum. Inilah yang biasa disebut dengan surat-surat keputusan, misalnya mulai dari Keputusan Presiden sampai Keputusan Bupati ataupun Walikota; dan

c. Bentuk putusan hakim yang biasa disebut vonis ataupun putusanputusan arbitrase yang apabila telah mempunyai kedudukan hukum yang tetap (in kracht) wajib dilaksanakan sebagaimana mestinya, misalnya putusan Mahkamah Agung, putusan Pengadilan Tinggi, putusan Pengadilan Negeri, atau putusan badan peradilan lainnya.

\section{Orientasi Penegakan Hukum}

\section{Hukum dibuat untuk ditegakkan}

Pembangunan hukum seringkali dipersempit maknanya hanya dalam konteks pembuatan hukum. Banyak orang yang berorientasi membangun hukum hanya dengan membuatnya. Urusan penegakan hukum, tidaklah dianggap sebagai tangungjawab pembuatnya. Akibatnya, para "legislator dan regulator" berbuat 
maksimal tanpa merasa perlu mempertimbangkan apakah aturan yang dibuatnya dapat atau tidak akan dapat ditegakkan dalam kenyataan praktek. Kecenderungan demikian ini memang sering terjadi di lingkungan negara-negara yang menganut tradisi civil law yang mengutamakan pembuatan peraturan yang tertulis oleh lembaga parlemen (legislator). Di lingkungan negara-negara yang menganut tradisi common law, hal seperti ini tidak terasa karena hukum utamanya dibuat oleh hakim (judge-made law) sesuai asas precedent. $^{7}$ Oleh karena itu, di lingkungan negara-negara dengan tradisi civil law seperti Indonesia penting sekali artinya untuk mempertimbangkan bahwa setiap peraturan perundang-undangan yang dibuat sudah sejak awalnya dipikirkan mengenai mekanisme pelaksanaannya di lapangan. Hukum tidaklah dibuat untuk sekedar melengkapi atau memperbanyak aturan, melainkan dibuat untuk ditegakkan atau dilaksanakan sebagaimana mestinya sebagai instrument yang diharapkan dapat memelihara dan menjamin keadilan dalam kehidupan bermasyarakat dan bernegara.

Dengan perkataan lain, untuk mengharapkan tegaknya hukum itu dipersyaratkan bahwa materi hukum itu sendiri memenuhi syarat untuk tegak dan ditegakkan dalam praktek. Namun, tegaknya hukum itu sendiri juga tidak hanya berkaitan dengan materi hukumnya itu sendiri. Tegaknya hukum juga mebutuhkan aparatur yang memang dapat bekerja efektif untuk menegakkan hukum itu. Sementara itu, warga masyarakat pada umumnya sebagai subjek hukum yang dituntut untuk menaati hukum juga sangat menentukan tegak tidaknya suatu norma hukum itu dalam kenyataan. Karena itu, dapat dikatakan ada tiga factor penting yang menentukan tegak tidaknya hukum dalam praktek, yaitu: (i) materi hukumnya memenuhi syarat untuk mendapat dukungan social (social support) dan ditaati oleh para subjek hukum yang luas, (ii) aparatur penegak hukumnya bekerja fungsional dan efektif, baik sebagai teladan maupun dalam upaya menegakkan hukum, dan (iii) para subjek hukum menjadikan norma hukum yang bersangkutan sebagai pedoman perilaku yang dengan sungguh-sungguh berusaha ditaati.

\section{Syarat-syarat materi hukumnya}

Untuk dapat diterima dan ditaati secara luas, norma hukum haruslah memenuhi syarat-syarat juridis yang sah (legal), syarat-syarat politik yang absah

\footnotetext{
${ }^{7}$ Jimly Asshiddiqie, Agenda Pembangunan Hukum di Abad Globalisasi (Balai Pustaka : Jakarta, 1996)
}

Jurisprudentie | Volume 4 Nomor 1 Juni 2017 
(legitimate $^{8}$, dan syarat-syarat-syarat sosiologis yang kuat. Pertama, legalitas suatu norma hukum secara juridis mencakup tiga syarat, yaitu: (i) bahwa norma hukum yang bersangkutan tidak bertentangan dengan norma yang lebih tinggi ${ }^{9}$, (ii) norma hukum yang bersangkutan ditetapkan menurut prosedur yang sah untuk itu $^{10}$, dan (iii) norma hukum yang bersangkutan ditetapkan oleh lembaga yang memang berwenang untuk itu. Kedua, legitimasi norma hukum yang bersangkutan secara politik mencakup dua syarat, yaitu: (i) bahwa norma hukum yang bersangkutan mendapat dukungan opini publik atau wacana dominan (dominant public discourse) dalam masyarakat ${ }^{11}$. Biasanya dukungan ini ditandai oleh dukungan yang tercermin dalam pemberitaan media massa, suara kalangan universitas, dan kalangan aktifis organisasi non-pemerintah; (ii) bahwa norma hukum yang bersangkutan mendapat dukungan mayoritas suara partai politik yang tercermin dalam suara mayoritas anggota parlemen; Ketiga, dukungan sosiologis masyarakat luas terhadap norma hukum yang bersangkutan mencakup tiga syarat berikut: (i) bahwa norma hukum yang bersangkutan diketahui dan dimengerti oleh para subjek hukumnya ${ }^{12}$; (ii) bahwa norma hukum yang bersangkutan diakui adanya dan daya ikatnya oleh para subjek hukum yang bersangkutan ${ }^{13}$; (iii) bahwa

${ }^{8}$ Konsep legalitas berbeda dari konsep legitimasi. Legalitas merupakan konsep hukum yang bersifat normatif dan hitam-putih, sedangkan legitimasi merupakan konsep politik yang bersifat dinamis. Sesuatu yang 'legal' secara juridis, belum tentu 'legitimate' dari kacamata hukum. Sebaliknya, sesuatu yang 'legitimate' dari kacamata politik belum tentu legal dari kacamata hukum.

${ }^{9}$ Ingat prinsip hirarki hukum yang dikembangkan berdasarkan 'stuffenbau-theorie' Hans Kelsen dalam bukunya General Theory of Law and State.

${ }^{10}$ Lihat teori yang dikembangkan oleh van Zevenbergen seperti didiskusikan oleh Soerjono Soekanto dalam Masalah Kedudukan dan Peranan Hukum Adat, Academia, Jakarta, 1979, hal. 56.

${ }^{11}$ Di antara para ahli yang mendiskusikan soal wacana dominant ini secara mendalam adalah Antonio Gramci dalam berbagai bukunya yang menjadi rujukan banyak ahli.

${ }^{12}$ Soal pengetahun dan pengertian masyarakat inilah yang menjadi salah satu pokok masalah yang dihadapi oleh negara besar dengan tingkatan perkembangan masyarakat yang sangat heterogin dan tidak merata seperti Indonesia sangat sulit untuk mempraktekkan doktrin 'teori fiktie' dalam hukum tanpa ekses atau dampak negatif. Karena itu, selain pembuatan hukum dan penegakan hukum, negara seperti Indonesia harus mengembangkan kebijakan tersendiri dalam rangka sosialisasi hukum dan penyebarluasan hukum dalam arti yang luas.

13 Teori pengakuan masyarakat (anerkennungstheorie) ini merupakan salah satu variasi teori sosiologi hukum, di samping teori reception seperti yang dikembangkan Snouck Hurgronje (teori receptie). Diskusi tentang ini, lihat Sayuti Thalib, Receptie A Contrario, Academia, Jakarta, 1980 dan juga dalam Pembaruan Hukum Islam di Indonesia, Yayasan Penerbit UI, Jakarta, 1977, hal.46. 
norma hukum itu diterima ${ }^{14}$ sebagai pedoman perilaku oleh para subjek hukumnya, karena memang sesuai dengan perasaan keadilan yang dianutnya.

\section{Syarat-syarat aparatur penegak hukumnya}

Meskipun materi hukumnya sudah memenuhi syarat, tetapi aparatur penegaknya tidak dapat diharapkan bekerja efektif, tetap tidak mudah bagi kita mengharapkan hukum dapat tegak sebagaimana mestinya. Karena itu, peranan aparatur penegak hukum betapapun juga haruslah dianggap sangat penting. Ada dua aspek penting yang tercakup dalam perkataan aparatur, yaitu: (i) institusinya, dan (ii) sumberdaya manusianya atau aparat (actor). Berfungsi efektifnya aparatur penegakan hukum tergantung pada aparat dan derajat pelembagaan institusi aparatur penegakan hukum itu sendiri.

Dari segi institusinya, diperlukan adanya (a) tata aturan organisasi dan tata laksana atau mekanisme kerja yang rasional dan sesuai prinsip-prinsip profesionalisme, baik yang bersifat internal, antar lembaga sejenis maupun antara lembaga penegak hukum yang satu dengan lembaga lainnya dalam kerangka sistem penegakan hukum terpadu, (b) sistem informasi yang mendukung profesionalisme kerja, baik yang bersifat internal, antar lembaga maupun antara lembaga penegak hukum, (c) sarana dan prasarana penunjang yang memadai, (d) dukungan dana yang mencukupi. Sedangkan dari segi sumberdaya manusia atau aparatnya, diperlukan (a) kualifikasi personil yang dapat diandalkan, (b) jumlah yang mencukupi sesuai kebutuhan, (c) tingkat kesejahteraannya yang relatif terjamin dengan baik, dan (d) idealisme pemimpin di semua lapisan kepemimpinan berdasarkan sistem kepemimpinan yang dapat memberi teladan.

Secara normatif, kedelapan faktor tersebut sangat mempengaruhi efektif tidaknya fungsi aparatur penegakan hukum dalam mendorong bekerjanya sistem hukum secara keseluruhan. Jika materi hukumnya telah memenuhi syarat-syarat sebagaimana dikemukakan di atas, dan aparatur penegakan hukumnya juga memenuhi kedelapan syarat tersebut, maka cita-cita negara hukum dapat diwujudkan dalam kenyataan, dan tegaknya hukum dan keadilan menjadi sesuatu yang nyata dalam kehidupan kita sehari-hari.

\footnotetext{
${ }^{14}$ Ibid.
} 


\section{PENUTUP}

Dari uraian di atas, negara hukum, pembangunan nasional berwawasan hukum dan orientasi penegakannya mendasarkan pada sepuluh prinsip pokok yang berlaku di zaman sekarang ini. Kesepuluh prinsip pokok sebagaimana telah disebut pada bagian pendahuluan di atas merupakan pilar utama yang menyangga kokohnya Negara Republik Indonesia, sehingga dapat disebut sebagai negara hukum sesuai makna yang tercantum dalam Pasal 1 ayat (3) UUD 1945. Di samping itu, konsep negara hukum itu didasarkan pula dengan paham negara yang ber-Ketuhanan Yang Maha Esa sebagaimana Sila Pertama Pancasila dan Pasal 29 ayat (1) UUD 1945, maka gagasan negara hukum modern Indonesia ditambah satu prinsip lagi, yaitu: Prinsip Berke-Tuhanan Yang Maha Esa sebagai prinsip kesebelas.

Langkah-langkah optimal dan sistematis perlu diambil agar pembangunan hukum nasional berkembang dengan baik, yakni perlu menggiatkan upaya pembaruan materi hukum nasional sesuai kebutuhan zaman dan sejalan dengan perkembangan nilai-nilai keadilan masyarakat. Selanjutnya, materi hukum nasional disosialisasikan melalui suatu program nyata dan dimasyarakatkan secara luas dan berkesinambungan, sehingga norma hukum yang berlaku diketahui, dimengerti, diakui, dan diterima dengan kesadaran oleh setiap warga negara. Dengan demikian, sistem penegakan hukum yang didukung oleh sistem kelembagaan maupun kualitas aparat dapat bekerja efektif, responsif, rasional dan impersonal terhadap setiap pelanggaran hukum yang terjadi. Akhirnya, tak kalah pentingnya dari langkah-langkah tersebut di atas perlu didukung oleh sistem informasi dan administrasi hukum modern sehingga mempermudah bekerjanya sistem hukum itu sendiri. 


\section{DAFTAR PUSTAKA}

Dicey, A.V. 1971. An Introduction to the Study of the Law of the Constitution, London: English Language Book Society and Macmillan

Jimly Asshiddiqie. 1996. Agenda Pembangunan Hukum di Abad Globalisasi. Jakarta: Balai Pustaka FHUI

Muhammad Tahir Azhary. 1992. Negara Hukum: Suatu Studi tentang Prinsipprinsipnya dilihat dari segi Hukum Islam, Implementasinya pada Periode Negara Madinah dan Masa Kini. Jakarta: Bulan Bintang

Neumann, Franz, The Rule of Law: Political Theory and the Legal System of Modern Society, Leamington Spa and Heidelberg, 1986.

Soerjono Soekanto. 1979. Masalah Kedudukan dan Peranan Hukum Adat. Jakarta: Academia

Sayuti Talib. 1977. Receptie A Contrario. Jakarta: Academia

1977. Pembaruan Hukum Islam di Indonesia, Jakarta: Yayasan Penerbit UI

Utrecht. 1962. Pengantar Hukum Administrasi Negara Indonesia. Jakarta: Ichtiar 